\title{
Knowledge of Banking Services among Frontline Personnel and Quality of Service Delivery in the Nigerian Commercial Bank
}

\author{
Adeniji Adenike Anthonia \\ Akinbode James Olalekan \\ Business Management Department \\ Covenant University, Ota, Ogun State, Nigeria
}

\author{
Keywords \\ Commercial bank, Frontline personnel, Knowledge, Quality, Service delivery,
}

\begin{abstract}
Service quality is no doubt one of the criteria used by existing customers or potential customers to make decision of their continued patronage or choice of service provider. However, knowledge gap of regulatory requirements cum standards among bank employees especially the frontline personnel have been reported as a factor which has contributed to inconsistent service quality delivery and service delivery failure to bank customers in Nigeria. It is against this background that this study assessed the extent to which knowledge of banking services among the frontline personnel is significant to quality of service delivery in the Nigerian Commercial Bank.

The study employed survey research design through which primary data were collected from four hundred and seventy-two $(N=472)$ bank customers of Union Bank Nigeria Plc. in Lagos State. Data was obtained through structured questionnaire. The data gathered were analyzed with both descriptive and inferential statistics. Results revealed that service quality delivery remains significant in the commercial bank and that there is a significant relationship between knowledge of banking services among frontline personnel and quality of service delivery in the Nigerian commercial bank. Based on the findings, the study concluded that knowledge of banking services among frontline personnel significantly influenced banking services delivery to customers and that the adequacy of the knowledge in banking services are significant to ensuring efficient quality service delivery in commercial bank. It was subsequently recommended that management of the banks should always train their staff while frontline personnel should promote knowledge sharing among themselves so as to continuously deliver quality services to customers.
\end{abstract}

Corresponding author: Akinbode James Olalekan

Email addresses for corresponding author: akinbodejo@gmail.com

First submission received: 31 ${ }^{\text {st }}$ March 2017

Revised submission received: $2^{\text {th }}$ October 2017

Accepted: $27^{\text {th }}$ November 2017

Introduction

Quality of service delivered to customers has been argued to be critical to customers' satisfaction, customer retention and contribute to continued existence of the business organization that provides the service (Okoe, Adjei, \& Osarenkhoe, 2013; Grönroos \& Ravald, 2011). This is because customers' perpetual demand for improved service quality has kept organizations in the service industry that desire survival in the highly competitive markets on their toes to continue to seek ways to provide high quality services or products. This is the reason why many of the organizations in the service industry including banks have adopted quality service delivery as one of their strategic tool for surviving in this highly competitive business environment. However, studies have identified gaps in the quality of service to customers in many industries and specifically the banking industry (Okoe, Adjei, \& Osarenkhoe, 2013; Gandhi, 2010).

Although many factors have been identified to be responsible for the lacuna between customers' expectations and perceptions of service delivery in service industry, the contribution of employees' knowledge in ensuring efficient service delivery to customers has been a global discussion over decades (Ahmed, 2011; Zhang, 2008). Precisely, front-line personnel no doubt play an important role in interacting with customers to deliver service. Frontline personnel are employees in front office who are often first 
contact in the organization located behind the counter, phone desk, or open floor. Therefore, their job related knowledge would count on their ability to address customers request at all times. In this wise, a good quality service might not sell itself if the representative of the service provider is deficit in knowledge or lack adequate knowledge of the services to either provide service or address the complaints of existing customers.

Commercial banks exist to offer some banking services such as account openings, deposit mobilization, advancing of loans, agency services such as making payments, collecting receipts, among others and general utility services such as issuing letters of credit, safe custody of valuables, among others. With the importance of this financial institution, customers cannot be left at the mercy of poor or inconsistent service delivery as currently been experienced by bank customers in Nigeria. Instances of inaccurate information supplied by frontline personnel have been experienced by customers. This shows that frontline personnel are expected to have detailed understanding of various bank services and its processes, knowledge of core banking system, regulatory laws, customer requirements, and various technology platforms in the bank, among others in order to deliver excellent service.

For the fact that existing customers are well informed about different kinds of services and their associated benefits, Kumasey (2014) remarked that this makes their expectations of service quality delivery high. With increase in customers' awareness of different banking services available from other banks, customers expect better and improved service delivery from their own bank. In line with this view, to an average customer; the efficiency of the service delivery system is captured in the reliability of the service delivery system (accuracy of service provided), and responsiveness of the service delivery system (timely reaction to customers' needs). All these would not be possible with frontline personnel deficit knowledge in banking services. Therefore, the central issue is to assess the extent to which frontline personnel knowledge in banking services contribute to quality service delivery to customers. The pertinent questions are:

1. Of what relevance is quality service delivery to customers in the commercial banks?

2. Can there be differences in the service delivery of a bank at branch levels?

3. What is the relationship between knowledge of banking services among frontline personnel and quality service delivery?

\section{Literature Review}

Service is a process consisting of a series of more or less intangible activities that normally, but not necessarily always, take place in interactions between the customer and service employees and/or physical resources or goods and/or systems of the service provider, which are provided as solutions to customer problems (Gronroos, 1984). Kotler and Keller (2012) described it as 'any intangible act or performance that one party offers to another that does not result in the ownership of anything'. Therefore, service varies in sectors. In the banking industry, different types of services have emerged but can be categorised into three major arms namely; general banking (accounts opening, deposit management and cash handling), credit (loan disbursement and loan management) and foreign exchange (foreign currency and remittance management) (Masukujjaman \& Akter, 2010). The services constituted the expectations of the customers and the extent to which these expectations are met informs their judgment of service quality.

Jayaraman, Shankar and Hor (2010) summarised service quality as the difference between customer's expectations for the service encounter and the perceptions of the service received. Therefore, service quality delivery is the extent to which service provider is able to meet the expectations of customers of service required. Ramseook-Munhurrun, Lukea-Bhiwajee and Naidoo (2010) noted that service delivery occurs during the interactions between contact employees and customers. In this regards, employee's knowledge level of what the customer's require would be necessary to meet customers' needs. Dingle (1995) described knowledge as the understanding of fundamental principles required to accomplish a task. This was further clarified by Su-Chin, Jui-Shin and Hung-Chun, (2012) when they noted that it refers to a body of information about the theoretical and practical understanding of a subject. Ployhart and Moliterno (2011) define knowledge as the "understanding of principles, facts, and process". Within the banking industry, employees especially those in the frontline are expected to be knowledgeable in banking services. Services such as investment advice, savings, deposits, transfers of 
fund, loans and project financing, partnership funding, lending, client portfolio, among others are areas an average frontline personnel should be well informed about. Therefore, this knowledge-based approach encapsulates knowledge of facts and concepts, procedural knowledge of how to deliver services to customers effectively in the banking industry.

Service quality gaps model of Zeithaml, Berry and Parasuraman (1988) and knowledge based theory of Grant (1996) were explored to explain the importance of frontline understanding of banking services towards ensuring effective service quality delivery. According to Zeithaml et al. (1988), it is assumed that service performance gap is the incongruity between expectations from service and its actual delivery by service providers which are often represented by the frontline personnel who serve as the link between the organization and customers. While a number of factors can be responsible for the service quality incongruity, knowledge gap of frontline personnel could be more disastrous. Such incongruity has been responsible for poor or low service quality delivery to customers. In his own account, Grant (1996) believed that individual knowledge can propel effective quality service delivery. Contemporary managers are aware of this and that is why knowledge is cherished as one of the leading emerging resources modern organizations continually promote. Subsequently, they constantly consider how to develop their employees' knowledge especially those in the front office because of the caliber of customers that exist now. To meet customers' requests accurately and timely, highly knowledgeable frontline personnel is required.

A number of studies have looked into related issues to the discourse. In a study conducted among bank customers in Greece and Bulgaria by Petridou, Charalambos, Niki and Chris (2007), it was established that bank service quality is a leading performance metric that is used to rate a bank. Similarly, Arasli, Mehtap-Smadi and Katircioglu (2005) identified service quality delivery as important in the banking industry while Okoe, Adjei, and Osarenkhoe (2013) established that gaps exist between customers' expectations and perceptions of service delivery in all the banks based on service quality in the Ghanian banking sector.

In another study carried out by Gandhi (2010) to determine service quality among selected banks in India from customers' perspective, significant amount of variations were found among the banks with respect to the level of service quality offered by the three groups of banks. While customer expectations of service quality were highest in the PSU banks, private and foreign banks followed accordingly. It is thus important to look inwardly that is carry out bank intra study to know why service quality differs at different branch levels.

This variation in service quality delivery has been traced to knowledge gaps among the personnel of the organisations who provide the service. Ekpoh, Edet and Nkama (2013) study on staff development programmes and secondary school teachers' job performance in Uyo, Akwalbom State, Nigeria gave a clue that knowledge of the subject might be a determinant factor as they pointed out this in job delivery which in this context relate to service quality. In an earlier study, Ahmed (2011) analyzed services rendered by commercial banks in India and discovered that knowledge of bank employees regarding services are very important to service delivery to customers. In another related study conducted in Bangladesh by Uddin and Akhter (2012), they identified knowledge of employees as important in providing service to customer effectively and efficiently. Purohit and Avinash (2007) remarked that customers perception of different banks vary due to individual employees knowledge sufficiency. Similarly, Kulsrestha, Singh, Dash and Mohan (2013) in their study on the impact of training on service delivery among Indian banks discovered complete knowledge of bank products and services among employees to be imperative for excellent service delivery.

Specifically, studies have confirmed frontline personnel as one of the leading representative of the organization (Masdek, Abdulaziz \& Awang, 2011; Zhang, 2008) as such their knowledge level about the organization is very important to the customers and other stakeholders. In a study carried out in China, Zhang (2008) discovered that excellent service of hotels or restaurants is embodied in the service process of frontline employees. However, there is need to study this scenario in Nigeria especially in the banking industry as no study has been found in that area. 


\section{Methodology}

Survey design was adopted to know the opinion of customers about the quality of service delivery in relation to front personnel of the bank knowledge level of bank services. The study was carried out in the four main branches Union bank Nigeria Plc in Lagos metropolis that is Head Office Branch (Marina), Ilupeju Branch, Oba Akran and Apapa. The choice of banking was based on the fact that it is a knowledge-based industry while the choice of Union bank is based on the fact that it is one of the first generation banks, smarter in operation and recently rebranded. The study involved different categories of bank customers such as businessmen/traders, students/apprentice, salary earners, retiree and unemployed were involved in the study in order to have responses across the various possible status of bank customers and this was done at their convenience. Therefore, convenience sampling was used to select samples for the study in the banking halls of the commercial banks.

Data for this study were gathered through structured questionnaire. The questionnaire consisted of four sections. The first section was made up of the demographic profile of the customers, second section measured service quality, third section measures knowledge of banking services while the fourth section measured the relationship between frontline personnel knowledge of banking services and quality of service delivery. Sections two to four were placed on a 5-point Likert scale ranging from 1 = strongly disagree to $5=$ strongly agree. The questionnaire was pre-tested to standardize it before administering it on the bank customers. In all, five hundred and two (502) bank customers participated while only four hundred and seventy-two (472) questionnaires were found duly completed and used for data analysis. Data analyses were carried out with simple frequency table and percentage, Z-score, Scheffe Multiple Comparison, Chi-square, and Pearson Product Moment Correlation Coefficient (r-test).

\section{Results and Interpretation}

Table 1 presents the distribution of demographic profile of the respondents (customers). The first section on the table shows that two hundred and thirty-four (234) of the respondents were male while two hundred and thirty-eight (238) were female. This implied that both sexes were adequately captured in the survey. On the age group of the respondents, thirty-four (34) of the respondents were between the ages of 16 - 25 years, one hundred and sixty-six (166) of the respondents were between 26 - 40 years, one hundred and ninety-three (193) were between 41 - 55 years while seventy-nine (79) of the respondents were 56 years and above. It was overt that most of the respondents were between the ages of 41-55years.

For the respondents' marital status, fifty-five respondents were single; four hundred and twelve were married while five were divorced. With the highest number of respondents from the married circle, some levels of matured responses were assured from the survey. While for the highest educational qualification of respondents, eighty-three respondents holds primary school leaving certificate, one hundred and forty-eight respondents were holders of $\mathrm{O}^{\prime}$ Level certificate, eighty-eight of the respondents had either ND or NCE, one hundred and nine of the respondents were either HND/1 st Degree holders, thirty--two of the respondents had Master's Degree while twelve respondents had other qualifications not captured in the filters. Majority of the respondents were O'Level certificate holders (148) and HND/Degree holders (109) respectively. This suggests well educated respondents for the study.

For the last segment of the demographic profile of the respondents which captured the status of customers, one hundred and five of the respondents were either businessmen or traders, sixty-nine were either students or apprentice, two hundred and fourteen were salary earners, thirty-two were retirees while fifty-two were unemployed. It is believed that different categories of customers were adequately represented in the study.

Table 1: Summary of Demographic Profile of Bank Customers

\begin{tabular}{|c|c|c|c|c|c|c|}
\hline \multirow{2}{*}{\multicolumn{2}{|c|}{ Demographic Profile }} & \multicolumn{4}{|c|}{ Pseudonym of the Union Bank Main Branches in Lagos } & \multirow{3}{*}{\begin{tabular}{|l|} 
Total \\
234 \\
\end{tabular}} \\
\hline & & \multirow{2}{*}{$\begin{array}{c}\text { Branch 'A' } \\
62\end{array}$} & \multirow{2}{*}{$\begin{array}{c}\text { Branch 'B' } \\
57\end{array}$} & \multirow{2}{*}{$\frac{\text { Branch 'C' }^{\prime}}{59}$} & \multirow{2}{*}{$\frac{\text { Branch 'D' }^{\prime}}{56}$} & \\
\hline Gender & Male & & & & & \\
\hline & Female & 66 & 59 & 58 & 55 & 238 \\
\hline \multirow{3}{*}{ Age Group } & $16-25$ years & 8 & 10 & 8 & 8 & 34 \\
\hline & $26-40$ years & 39 & 37 & 41 & 49 & 166 \\
\hline & $41-55$ years & 46 & 42 & 49 & 56 & 193 \\
\hline
\end{tabular}

www.jbrmr.com A Journal of the Academy of Business and Retail Management (ABRM) 


\begin{tabular}{|c|c|c|c|c|c|c|}
\hline & 56 years \& Above & 18 & 19 & 20 & 22 & 79 \\
\hline \multirow[b]{3}{*}{ Marital Status } & Single & 13 & 12 & 15 & 15 & 55 \\
\hline & Married & 98 & 102 & 108 & 104 & 412 \\
\hline & Divorced & 0 & 2 & 1 & 2 & 5 \\
\hline \multirow{6}{*}{$\begin{array}{l}\text { Highest } \\
\text { Educational } \\
\text { Qualification }\end{array}$} & $\begin{array}{l}\text { Primary school } \\
\text { certificate }\end{array}$ & 27 & 22 & 18 & 16 & 83 \\
\hline & $\mathrm{O}^{\prime}$ Level & 42 & 36 & 31 & 39 & 148 \\
\hline & $\mathrm{ND} / \mathrm{NCE}$ & 26 & 19 & 22 & 21 & 88 \\
\hline & HND/1 ${ }^{\text {st }}$ Degree & 26 & 31 & 29 & 23 & 109 \\
\hline & Master's Degree & 5 & 9 & 8 & 10 & 32 \\
\hline & Others & 3 & 5 & 2 & 2 & 12 \\
\hline \multirow[t]{5}{*}{ Status of Customer } & Businessman/Trader & 23 & 21 & 27 & 34 & 105 \\
\hline & Student/Apprentice & 18 & 15 & 19 & 17 & 69 \\
\hline & Salary Earner & 49 & 54 & 52 & 59 & 214 \\
\hline & Retiree & 9 & 6 & 8 & 9 & 32 \\
\hline & Unemployed & 14 & 12 & 15 & 11 & 52 \\
\hline
\end{tabular}

Source: Computed Data, 2016.

\section{Test of Hypotheses}

Hypothesis 1 (Ho $\mathbf{H o}_{1}$ : Quality service delivery to customers is insignificant in the commercial banks

Generated data presented in Table 2 showed that calculated $Z=41.09$ which was greater that the critical $Z=1.64(Z=41.09>Z$ table value 1.64$)$. Hence, the null hypothesis which stated that quality service delivery to customers is insignificant in the commercial banks was rejected while the alternate hypothesis was accepted. This confirmed that quality service delivery to customers is significant in the commercial bank.

Table 2: Preference for Quality Service Delivery in the Commercial Bank

\begin{tabular}{|c|c|l|c|c|c|c|}
\hline & $\mathbf{N}$ & Mean & Std. Deviation & Cal & T & Rmk \\
\hline $\begin{array}{c}\text { Quality of Service } \\
\text { Delivery }\end{array}$ & 472 & 2.952 & .471 & 41.09 & 1.64 & Sig. \\
\hline
\end{tabular}

a. Predictor: (Constant), Quality service Delivery

b. Dependent variable: Commercial Bank

Source: Computed Data, 2016.

Hypothesis 2( $\left.\mathrm{Ho}_{2}\right)$ : There is no significant difference in the quality of service delivery of the bank branches.

Result as presented in Table 3 showed that there was a significant difference in the commercial bank branches quality of service delivery. To establish where the dissimilarity lies among the commercial banks, a post hoc analysis using Scheffe multiple comparisons as presented in table 3 revealed that the selected commercial bank branches were found to have significant difference in their service quality delivery. When commercial bank branch ' $A$ ' was compared with other commercial bank branches, it was revealed that there were significant differences when compared with commercial bank branches $B, C$ and D. Specifically, multiple comparison of commercial bank branch B with others showed that there was a significant difference in the quality of service delivery compared with commercial bank $C$ and that of commercial bank D.

Table 3: Scheffe Multiple Comparison of the Commercial Bank branches service quality delivery

\begin{tabular}{|c|c|c|c|c|}
\hline Branches of the Bank & Branches of the Banks & Mean Difference & Std. Error & Sig. \\
\hline \multirow{3}{*}{ A } & & & & \\
\cline { 2 - 4 } & B & $-5.21751^{*}$ & 1.37740 & .015 \\
\cline { 2 - 4 } & C & 3.64402 & 2.20671 & .582 \\
\hline \multirow{2}{*}{ B } & D & $9.17592^{*}$ & 2.01732 & .000 \\
\cline { 2 - 5 } & A & $5.25651^{*}$ & 1.47870 & .013 \\
\hline
\end{tabular}




\begin{tabular}{|c|c|c|c|c|}
\hline & $\mathrm{D}$ & $14.53325^{*}$ & 2.06438 & .000 \\
\hline \multirow{3}{*}{$\mathrm{C}$} & $\mathrm{A}$ & -5.72401 & 2.10654 & .562 \\
\cline { 2 - 5 } & $\mathrm{B}$ & $-10.11254^{*}$ & 2.23301 & .001 \\
\cline { 2 - 5 } & $\mathrm{D}$ & 4.43189 & 2.48638 & .617 \\
\hline \multirow{3}{*}{$\mathrm{D}$} & $\mathrm{A}$ & $11.33443^{*}$ & 2.31142 & .000 \\
\cline { 2 - 5 } & $\mathrm{B}$ & 5.00800 & 2.34203 & .361 \\
\cline { 2 - 5 } & $\mathrm{C}$ & $17.11856^{*}$ & 2.81651 & .000 \\
\hline
\end{tabular}

Source: Computed Data, 2016.

Hypothesis 3( $\left.\mathrm{Ho}_{3}\right)$ : There is no significant relationship between knowledge of banking services among frontline personnel and quality of service delivery in the Nigerian commercial bank.

To test for this hypothesis, knowledge of banking services among frontline personnel were crosstabulated with quality of service delivery, a process that generated a chi-square value with which the relationship that exists between personnel knowledge of banking services and quality of service delivery was determined as $\left(\chi^{2}=64.61, \mathrm{df}=4, \mathrm{p}<0.05\right)$ which implied that the relationship between personnel knowledge of banking services and quality of service delivery was significant. Therefore, null hypothesis was rejected and the alternate was accepted that there is significant relationship between knowledge of banking services among frontline personnel and quality of service delivery in the Nigerian commercial bank.

Table 4: The relationship between knowledge of banking services among frontline personnel and quality of service delivery

\begin{tabular}{|l|c|c|c|c|c|c|}
\hline \multirow{2}{*}{ Quality of service delivery } & \multicolumn{2}{|c|}{ Personnel Knowledge of banking services } & \multirow{2}{*}{$\chi^{\mathbf{2}}$} & Df & \multirow{2}{*}{ P } \\
\cline { 2 - 5 } & Poor & Good & Excellent & & & \\
\hline Poor Delivery & $29(49.2 \%)$ & $22(37.3 \%)$ & $8(13.6 \%)$ & \multirow{2}{*}{6} & \multirow{2}{*}{4} & \multirow{2}{*}{$<.05$} \\
\hline Average Delivery & $36(12.8 \%)$ & $217(77 \%)$ & $29(10.3 \%)$ & \multirow{2}{*}{64.61} & & \\
\hline Excellent Delivery & $22(16.8 \%)$ & $94(70.1 \%)$ & $15(11.5 \%)$ & & & \\
\hline
\end{tabular}

Source: Computed Data, 2016.

In other to ascertain the direction of the relationship established in Table 4, further analysis was carried out with Pearson correlation as presented in Table 5. The result confirmed positive relationship between knowledge of banking services among frontline personnel and quality of service delivery in the Nigerian commercial bank $(\mathrm{r}=0.153)$.

Table 5: Direction and relationship between frontline personnel knowledge of bank services and quality of service delivery

\begin{tabular}{|l|c|c|c|c|c|}
\hline \multicolumn{1}{|c|}{ Variables } & N & Mean & Std. Deviation & R & Sig. (2-tailed) \\
\hline $\begin{array}{l}\text { Knowledge of frontline } \\
\text { personnel Score }\end{array}$ & 472 & 43.7383 & 3.58631 & $0.153^{\text {*** }}$ & 0.0000 \\
\hline $\begin{array}{l}\text { Quality of service delivery } \\
\text { score }\end{array}$ & 472 & 42.5098 & 13.60374 & & \\
\hline
\end{tabular}

**. Correlation is significant at the 0.01 level (2-tailed).

Source: Computed Data, 2016.

\section{Discussions of Findings}

This study investigated the relationship between knowledge of banking services among frontline personnel and quality of service delivery in the Nigerian commercial bank. The Z-Score test from the study confirmed that quality service delivery to customers is significant in the Nigerian commercial banks. Thus, commercial banks must never undermine the quality of service delivery to customers if they want to remain in business. This finding is consistent with an earlier study conducted by Petridou, Charalambos, Niki and Chris (2007) and Arasli, Mehtap-Smadi and Katircioglu (2005) which found out that quality of service delivery is important in the banking industry. According to Petridou, Charalambos, Niki and Chris (2007), bank service quality is a leading performance metric that is used to rate a bank as such banks do not undermine the quality of their services to customers. The study also revealed that there was a significant difference in the commercial bank branches quality of service delivery. This affirmed the fact that despite the branches are under one central management, variation were found on the ground that 
knowledge of frontline personnel about banking services varies and makes the level of service quality offered in these branches to be different. Scheffe multiple comparisons showed that quality of service delivery among the selected commercial bank branches differs significantly.

Results of the study further indicated that there is significant relationship between knowledge of banking services among frontline personnel and quality of service delivery in the Nigerian commercial banks. Consequently, frontline personnel of the banks are expected to always have adequate knowledge of the banking services in order to be able to deliver services effectively to customers. This finding further reaffirmed Grant (1996) knowledge theory which believed that individual knowledge is essential to effective quality service delivery. This finding is consistent with that of Ekpoh, Edet and Nkama (2013) which found out that knowledge bring about effective job performance. It was further established that the relationship is positive. Specifically, the finding support the positions of Uddin and Akhter (2012) and Ahmed (2011) which discovered that knowledge of bank employees regarding services are very important in service delivery to customers. Thus, commercial banks that desired improved service delivery to her customers must seek how to boost frontline personnel knowledge of bank services all the time. In other words, to improve upon quality of service delivery to customers, there is a need to equip frontline personnel with adequate knowledge of bank services.

\section{Conclusion}

Excellent service quality delivery in banking industry cannot be achieved without adequate knowledge of banking services by frontline personnel of the bank. Frontline personnel knowledge gap of banking services will result into low or poor service delivery to customers. With the grasp knowledge of banking services of the frontline personnel in the opinion of customers, excellent service quality delivery to customers of the bank is certain. It was the belief of this study that knowledge gap among the frontline personnel from one branch of the bank to the other contribute to the differences in their service delivery level. With these findings, commercial banks need to always furnish their frontline personnel adequate information about banking services as they are the first contact between the customers and the bank.

\section{Recommendations}

Based on the findings of the study, the following recommendations were made:

1. It was established that existing knowledge of services can be outdated, continuous training of both core and outsourced staff thus become imperative for up-to-date knowledge of different service areas of the bank in order to ensure top service quality.

2. Efficient information sharing platform among staff especially for the front line personnel should be encouraged to deliver excellent services to customers.

3. Frontline personnel without professional trainings in customer relationship management should be encouraged to pursue one as it is a panacea towards promoting quality service delivery to customers.

\section{Limitations and Suggestions for Further Studies}

The study was carried out in the main branches of Union Bank of Nigeria Plc in Lagos State, Nigeria. One of the observed areas that can give more insight into the issues is to either carry out interstate study of the bank or geopolitical zones study in the same bank. A further study can also be done between or among commercial banks in Nigeria in Lagos State or interstate or along geopolitical zones of the country to rank the Nigerian commercial banks in terms of service quality delivery to customers.

\section{References}

Ahmed, J. U. (2011). Services rendered by commercial bank: customer oriented empirical evidence from State bank of India. Management Convergence, 1(2), 63-82.

Arasli, H., Mehtap-Smadi, S., \& Katircioglu, S. T. (2005). Customer service quality in the Greek Cypriot banking industry. Managing Service Quality, 15(1), 41-56.

Dingle, J. (1995). Analyzing the competence requirements of managers. Management Development Review, $8(2), 30-36$.

Ekpoh, U. I., Edet, A. O., \& Nkama, V. I. (2013). Staff development programmes and secondary school teachers job performance in Uyo metropolis, Nigeria. Journal of Education and Practice, 4(12), 217-222. 
Grant, R. (1996). Toward a knowledge-based theory of the firm. Strategic Management Journal, 17 (Winter), 109-122.

Gronroos, C. (1984). A service quality model and its marketing implications. European Journal of Marketing, 18(4), 36-44.

Grönroos, C., \& Ravald, A. (2011). Service as business logic: implications for value creation and marketing. Journal of Service Management, 22(1), 5-22.

Jayaraman, M., Shankar, C. \& Hor, W. M. (2010). Service quality delivery and its impact on customer satisfaction in the banking sector in Malaysia. International Journal of Innovation, Management and Technology, 1(4), 398-404

Kotler, P. \& Keller, K. L. (2012). Marketing Management. 14th Edition ed. New Jersey: Prentice Hall.

Kulsrestha, N., Singh, K. L., Dash, K. S., \& Mohan, S. (2013). The impact of training on service delivery in banking sector: A case study in selected Indian banks. International Journal of Contemporary Business Studies, 4(6), 11-19.

Kumasey, A. S. (2014). Service quality and customer satisfaction: Empirical evidence from the Ghanaian public service. European Journal of Business and Management, 6(6), 172-181.

Masdek, N. N., Abdulaziz, Y. \&Awang, K. W (2011). Potential antecedents and outcomes of frontline employees' service recovery performance. International Journal of Economics and Management, 5(1), $114-139$.

Masukujjaman, M. \& Akhter, A. (2010). Quality of categorized service and customer satisfaction in banking industry: An empirical study on private commercial bank in Bangladesh.Journal of Business and Technology, 5(2), 17-29.

Nawaz, M., Shakoor, M. I., \&Pirzada, S. S. (2013). The professional development of employees in banks of Pakistan: A comparative study of public and private banks in Punjab Pakistan. International Journal of Learning and Development, 3(5), 89-110.

Okoe, A. F., Adjei, J. S., \& Osarenkhoe, A. (2013). Service quality in the banking sector in Ghana. International Journal of Marketing Studies, 5(2), 81-92.

Petridou, E., Charalambos, S., Niki, G., \& Chris, L. (2007). Bank service quality: Empirical evidence from Greek and Bulgarian retail customers. International Journal of Quality and Reliability Management, 24(6), 568-585.

Ployhart, R. E., \& Molitierno, T. P. (2011). Emergence of the human capital resource: A multilevel model. Academy of Management Review, 36(1), 127-150.

Purohit,H. C. \&Avinash, D. P. (2007). Service quality measurement and consumer perception about the services of banking institutions. Indian Journal of Marketing, 47(3), 1-12.

Ramseook-Munhurrun, P., Lukea-Bhiwajee, S. D. \& Naidoo, P. (2010). Service quality in the public service. International Journal of Management and Marketing Research, 3(1), 37 - 50.

Su-Chin, H., Jui-Shin, L. \& Hung-Chun, L. (2012). Analysis on literature review of competency. International Review of Business and Economics, 2, 25-50.

Uddin, M. B. \& Akhter, B. (2012). Determinants of customer satisfaction of banking industry in Bangladesh. Pakistan Journal of Commerce Social Sciences, 6(2), 242- 256.

Zeithaml, V. A., Berry, L. L. \& Parasuraman, A. (1988). Communication and control processes in the delivery of service quality. Journal of Marketing, 52(April), 35-48.

Zhang, Y. (2008). Problems existing in China's hotel service and study on the strategy from the aspect of customer value. Journal of Politics and Law, 1(2), 60-63.

\section{Acknowledgment}

We sincerely appreciate the management of Covenant University for the support and sponsorship of this research work. 